DEAIOS-95ER $6205 \%$

FINAC REPORT

Correspondence to: Dr. Henry F. Diaz

NOAA/ERL/CDC

325 Broadway

Boulder, CO 80303

phone: (303) 497-6649

fax (303) 497-7013

e-mail hfd@cdc.noaa.gov

Workshop Report

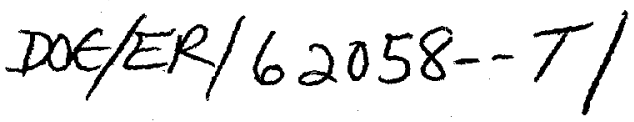

Submitted for publication to the EOS Section on News \& Announcements

\title{
Climatic Change at High Elevation Sites
}

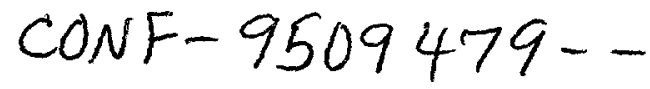

A Workshop on climatic change at high elevation sites was held September 11-15, 1995 in Wengen, Switzerland. The meeting was sponsored by both U.S. (Department of Energy, National Science Foundation and National Oceanic \& Atmospheric Administration) and European (Swiss Nitional Science Foundation, European Science Foundation, Swiss Federal Institute of Technology) agencies. The goals of the workshop were to 1) focus the attention of the world climate community on the existence of unique high elevation geophysical records around the world, 2) highlight the value of these observing sites for climate change detection efforts and to help insure the continued support of governments and of relevant institutions in the maintenance of these high elevation data gathering efforts, 3) discuss and evaluate climatic trends that may be present in these records, and to compare the information with available paleoenvironmental records of glaciers, tree-rings and varved sediments from the alpine zones, and 4) discuss and evaluate information about elevational differences in current and projected greenhouse-gas induced climatic changes in coupled General Circulation Models.

The workshop attracted over 50 scientists from 12 countries who presented 44 papers on topics which were divided into three thematic parts. After a couple of introductory lectures, which highlighted the importance of the world's high elevation areas for gaining a deeper understanding of the global climate system, and a review of the 1995 Intergovernmental Panel on Climate Change (IPCC) Scientific Assessment dealing with climate changes in mountain regions, papers were presented dealing with i) temporal and regional climate variability in mountainous areas, ii) inferences of climatic changes from tree-ring records, and iii) inferences of climatic changes from glacial, isotopic, and other proxy data. After each workshop session a plenary discussion was beld to review the results of the talks and to arrive at a few salient recommendations with regard to the need for further studies and/or monitoring activities, and to attempt to reach some consensus 


\section{DISCLAIMER}

This report was prepared as an account of work sponsored by an agency of the United States Government. Neither the United States Government nor any agency thereof, nor any of their employees, make any warranty, express or implied, or assumes any legal liability or responsibility for the accuracy, completeness, or usefulness of any information, apparatus, product, or process disclosed, or represents that its use would not infringe privately owned rights. Reference herein to any specific commercial product, process, or service by trade name, trademark, manufacturer, or otherwise does not necessarily constitute or imply its endorsement, recommendation, or favoring by the United States Government or any agency thereof. The views and opinions of authors expressed herein do not necessarily state or reflect those of the United States Government or any agency thereof. 


\section{DISCLAIMER}

Portions of this document may be illegible in electronic image products. Images are produced from the best available original document. 
about the main scientific findings in each session. Following is a summary of the major recommendations agreed to by the workshop participants.

In the area of instrumental records, participants identified a set of unique climate records taken in pristine environments at high elevation. Among these unique mountain top records are the long climate series taken at Sonnblick, Austria, Pic du Midi, France, and at Saentis and Jungfraujoch, Switzerland. There are many others that have been identified and for which climate records are avallable from a variety of sources. A key goal of the broader climate community is the preservation and continuation of climate observations at these high elevation sites, and the promotion of free and open access and exchange of these data to researchers. A representative of the World Meteorological Organization, in attendance at the workshop, agreed, in principle, about the special nature of these observing sites for the monitoring of climate changes, and for comparison with the climate record of sites situated in low valleys and near sea level, where most of the world's population lives.

A number of studies and observations indicate that during the past two decades there has been a general retreat of alpine glaciers in many areas of the world. Similarly documented increases in tropical sea surface temperature and rainfall, and some evidence of an increase in humidity in the lower tropical troposphere, suggest that the climate in upper montane regions may have been disprop stionately impacted by these large-scale climate changes. Analysis of instrumental data indicate that the surface temperature increases of the last couple of decades are equally, and in some cases, more strongly reflected at higher elevations, although there are strong regional and seasonal differences. The evidence also indicates that mean monthly minimum temperature exhibits the greatest elevational signal compared to the mean monthly maximum and the average monthly temperature values. An examination of doubled $\mathrm{CO}_{2}$ general circulation model climate simulations leave open the question of a possible amplification of the greenhouse warming signal below about $4 \mathrm{~km}$, but preliminary results show a possible increase in surface temperature relative to sea level values of between $0.5-1.5^{\circ} \mathrm{C}$ at about $4 \mathrm{~km}$ in tropical latitudes $\left(35^{\circ} \mathrm{N}-35^{\circ} \mathrm{S}\right)$.

Studies of precipitation changes with elevation are hampered by an increase in measurement bias due to the general increase of wind speed with height, which results in lower measured precipitation values than is actually true. Work aimed at reducing the precipitation measurement bias in Swiss alpine areas was presented, which included a comparison of area-averaged precipitation values with runoff measurements. The results suggest that the present precipitation gage network underestimate the true values by 10 $20 \%$. the Another approach to inferring decadal-scale changes in land precipitation is to 
look at atmospheric circulation changes over a similar time frame. The changes in European precipitation observed over the last 20 years, are consistent with a persistent pattern of sea level pressure and mid-tropospheric geopotential height fields associated with the North Atlantic Oscillation (NAO). For winter, this persistent NAO mode has promoted warmer and drier than normal winters in central and southern Europe, while at the same time, northern Europe, and particularly Scandinavia, have tended to experience winters which were colder and wetter than average. As a result, glcier mass balance in Iceland and Scandinavia has been strongly positive in the last 20 years, whereas glaciers in the European Alps have experienced significant mass losses, with some smaller glaciers and ice fields disappearing entirely.

Tree-ring studies for many parts of the world show well-documented patterns of climatic variations on a broad range of temporal and spatial scales. It was emphasized that the interpretation of the results depends critically on the care with which the sites and tree species are selected. Other factors that must be borne in mind when developing a climatic interpretation of dendroclimatic reconstructions, deal with the statistical filtering that is employed to remove biological growth effects, and the fact that, in general, these reconstructions primarily show changes in growing season temperature and precipitation, rather than climatic signals for the other seasons or for the year. Nevertheless, the representative studies in dendroclimatology presented at the workshop indicate broad similarities, as well as some differences, in the regional expression of climatic variations in different parts of the world, and between Northern and Southern Hemisphere sites.

Studies of isotopic and depositional changes preserved in ice cores, tree stumps found in the vicinity of modern glacier margins (denoting trees that were killed during past glacial advances and which can be dated precisely from their growth rings), and studies of past upper catchment climate changes preserved in lake varves, all show significant climatic variability during Holocene times, including major changes that took place in Europe during the most recent deglaciation phase (after $\sim 14 \mathrm{ka} \mathrm{BP}$ ). The picture of large natural climate changes in the last several thousand years needs to be kept in mind when assessing recent changes in climate. Nevertheless, persuasive data from a number of widely separated tropical ice caps is becoming available, which shows that the last 50 or so years are among the warmest of the last several thousand years. This unprecedented warming of the tropical atmosphere has been dramatically illustrated in recent years by the melting of ice layers that had, hitherto, been preserved for centuries. Furthermore, many high elevaltion glaciers and ice caps are retreating or disappearing at a rapid rate. The evidence presented at the workshop also indicates that warming at high elevations in the tropics is at least as great as that observed at higher latitudes. Both the geophysical 
records and the limited instrumental data available for high tropical sites, suggest that increased attention should be paid to this region and that a number of sensitivity tests with a suite of GCMs should be carried out to evaluate the relative climatic sensitivity of this region to global change.

The rapid loss of alpine glaciers and ice caps such as is occurring in many parts of the world, will have serious consequences for a wide range of human activities. Among the most seriou, socioeconomic impacts will be those associated with changes in runoff, which will have a direct effect on water resources management, including hydropower generation, water quality, the bealth of aquatic ecosystems, and the possible loss of tourist business in the areas affected. A special issue of the journal Climatic Change, containing papers derived from work presented at this workshop is planned.

This item was contributed by Henry F. Diaz, National Oceanic and Atmospheric Administration/Environmental Research Laboratories, Boulder, Colorado, Martin Beniston, Swiss Federal Institute of Technology, Zurich, Switzerland and Raymond S. Bradley, Department of Geosciences, University of Massachusetts, Amherst, Massachusetts. 